Acta vet. scand. $1972,13,251-259$.

The Department of Food Hygiene and the Department of Microbiology and Immunology, Veterinary College of Norway, Oslo.

\title{
THE PRODUCTION AND SOME PROPERTIES OF THE BROWN PIGMENT OF AEROMONAS LIQUEFACIENS
}

\author{
By \\ Kjell Aurstad and Hans Kolbein Dahle
}

\begin{abstract}
AURSTAD, KJELL and HANS KOLBEIN DAHLE: The production and some properties of the brown pigment of Aeromonas liquefaciens. Acta vet. scand. 1972, 13, 251-259. - The optimum conditions for pigment production by Ae. liquefaciens was found to be $30^{\circ} \mathrm{C}$ and aerobic incubation, and the properties of the pigment are shown to be similar to those of the synthetic dopa-melanin referred to. The enzyme phenol oxidase was demonstrated in the culture filtrates, but not in extracts of disintegrated cells. As precursors for the pigment production, which was shown to be strictly $\mathrm{pH}$ dependent, DL-tyrosine, DL-dopa and catechol were used with success, while numerous other amino acids failed. The significance of the pigment as a criterium for the identification of strains which are pathogenic to certain animals or fishes, is not known.
\end{abstract}

pigment, ba cterial; me la nin, bacterial;

Aeromonas liquefaciens; fish diseases, bacterial.

The brown pigment of Aeromonas salmonicida (Bacterium salmonicida) has previously been shown to be of the melanin type of pigments (Griffin et al. 1953). Some workers consider the pigment to be a valuable criterium for the identification of strains of Ae. salmonicida, which may give rise to furunculosis in salmon and trout (Holt \& Håstein 1970). Ae. liquefaciens is considered to be less pathogenic for salmonoids than Ae. salmonicida, although several reports indicate that this organism may be pathogenic to both salmonoids and to some other species (Carberry 1968, Meyer 1964, Rock \& Nelson 1965). Dahle (1969) found a close enzymoserological relationship between Ae. liquefaciens and Ae. salmonicida, and substantial interest should 
therefore be given to the properties and significance of the brown pigment produced by Ae. liquefaciens (Ross 1962).

The aim of the present work was to elucidate the nutritional requirements for the production of the brown pigment of Ae. liquefaciens and to clarify some of its properties.

\section{MATERIALS AND ME'THODS}

Strain

The strain used was Aeromonas liquefaciens ATCC 14715, obtained from the American Type Culture Collection, Rockville, Maryland, USA.

\section{Media}

The basal medium contained the following ingredients in distilled water: $\mathrm{NH}_{4} \mathrm{Cl}, 5 \mathrm{~g} ; \mathrm{NH}_{4} \mathrm{NO}_{3}, 1 \mathrm{~g} ; \mathrm{Na}_{2} \mathrm{SO}_{4}, 2 \mathrm{~g} ; \mathrm{K}_{2} \mathrm{HPO}_{4}, 3 \mathrm{~g} ; \mathrm{KH}_{2} \mathrm{PO}_{4}, 1 \mathrm{~g}$; $\mathrm{MgSO}_{4} \cdot \mathrm{H}_{2} \mathrm{O}, 0.2 \mathrm{~g} ; \mathrm{H}_{3} \mathrm{BO}_{4}, 6 \cdot 10^{-5} \mathrm{~g} ; \mathrm{MOO}_{3}, 3 \cdot 10^{-5} \mathrm{~g} ; \mathrm{Fe}\left(\mathrm{NH}_{4}\right)_{2}\left(\mathrm{SO}_{4}\right)_{2}$, $0.6 \cdot 10^{-3} \mathrm{~g} ; \mathrm{MnSO}_{4} \cdot 4 \mathrm{H}_{2} \mathrm{O}, 0.8 \cdot 10^{-3} \mathrm{~g} ; \mathrm{CuSO}_{4} \cdot 5 \mathrm{H}_{2} \mathrm{O}, 4 \cdot 10^{-3} \mathrm{~g} ; \mathrm{ZnSO}_{4} \cdot$ $7 \mathrm{H}_{2} \mathrm{O}, 88 \cdot 10^{-3} \mathrm{~g}$; glucose $10 \mathrm{~g}$ and DL-glutamine $10 \mathrm{~g}$. The volume was adjusted to $1000 \mathrm{ml}$.

In some experiments measured amounts of defined ingredients as ascorbic acid, thiouracil and certain amino acids were added directly into tubes containing $5 \mathrm{ml}$ of the basal medium, and the total medium was sterilized at $121^{\circ} \mathrm{C}$ for $15 \mathrm{~min}$. The peptone water used, contained peptone (Difco ${ }^{*}$, Bacto peptone, 0118-01) $1.0 \%$ and $\mathrm{NaCl}$ $0.5 \%$. Milk agar was prepared by adding skim milk to nutrient agar to a final concentration of $10 \%$.

\section{Experimental conditions}

The organism was inoculated into $5 \mathrm{ml}$ volumes of liquid medium in $20 \mathrm{ml}$ glass tubes and incubated for 2-10 days, both aerobically and anaerobically, at $20^{\circ} \mathrm{C}, 30^{\circ} \mathrm{C}$ and $37^{\circ} \mathrm{C}$. The pigment production was also examined on skim milk agar cultures under the same conditions.

\section{Isolation of the pigment}

The pigment of Ae. liquefaciens was precipitated from culture filtrates obtained by filtration of the cultures through a Millipore ${ }^{\star *}$ filter $(0.45 \mu)$. The culture filtrates prepared, were adjusted to $\mathrm{pH}$ 7.0 and the pigment was precipitated by the addition of $1 \mathrm{~g}$ potassium persulphate per $100 \mathrm{ml}$, and then the solution was allowed to stand for $2 \mathrm{hrs}$. with occasional shaking. After adding $100 \mathrm{ml}$ of methanol per $10.0 \mathrm{ml}$ of filtrate, the mixture was allowed to stand for a further 3 days. During this time the pigment was precipitated, and was collected by centrifugation (Blackberg \& Wanger 1933, Mencher \& Heim 1962).

* Difco Laboratories Inc, Michigan, USA.

* Millipore Ltd., Wembley, Middlesex, England. 


\section{Demonstration of the enzymatic activity}

Culture filtrates, or extracts from 3 times washed and disintegrated cells, were added to wells of $7 \mathrm{~mm}$ diameter in a $1 \%$ agar gel containing $0.1 \%$ DL-tyrosine, DL-dihydroxyphenylalanine (DL-dopa) or catechol as substrates (Cooper \& Brown 1956). Control gels were run without substrate. Enzyme activity was also demonstrated in tubes containing $0.5 \mathrm{ml} 0.2 \%$ DL-dopa, $0.5 \mathrm{ml} 0.2 \%$ DL-tyrosine or $0.5 \mathrm{ml}$ $0.2 \%$ catechol to which $0.5 \mathrm{ml}$ culture filtrate, or $0.5 \mathrm{ml}$ extracts of the disintegrated cells, were added. Disintegration of the cells was carried out by using an X-press ${ }^{*}$, the frozen material being pressed 3 times through a hole with a diameter of $2.5 \mathrm{~mm}$.

\section{RESULTS}

\section{Conditions for pigment production}

The liquid cultures of Ae. liquefaciens in peptone water and the agar cultures on skim milk agar grew well at $25^{\circ} \mathrm{C}$ and $30^{\circ} \mathrm{C}$ when incubated aerobically, while at $37^{\circ} \mathrm{C}$ there was less growth. Although the cultures also grew well when incubated anaerobically, the pigment was only produced when the organism was grown aerobically. The optimum temperature for production of visible amounts of pigment was found to be $30^{\circ} \mathrm{C}$, which corresponds to the optimum temperature for growth. After 15 to 20 hrs. of incubation the organism had grown well, but the formation of visible amounts of the pigment in the medium usually required an additional incubation for 10 to $20 \mathrm{hrs}$. At the end of this period a very faint pinkish colour was sometimes detected on the milk agar, or it occurred as a yellow-brownish colour in the peptone water. It was a general finding that the pigment was concentrated in the upper part of the culture tubes. After a further 3 days the colour changed from pink to redamber, and after 5 days, or more, the colour of the entire skim milk agar or peptone water was brown to black.

The colonies on the skim milk agar remained nearly colourless during the first period of pigment production ( $40 \mathrm{hrs}$.), but after further incubation for 2 days, the colonies also became light brown.

\section{Properties of the pigment}

The pigment was isolated by the methanol procedure of Mencher \& Heim (1962). The solubility in distilled water was

\footnotetext{
* AB Biox, Box 235, Nacka 2, Sweden.
} 
negligible at $\mathrm{pH} 7.0$, but addition of $0.1 \mathrm{~N}-\mathrm{NaOH}$ to a $\mathrm{pH}$ value above 10.0 led to a great increase in solubility. For spectrophotometrical examinations, the pigment was dissolved in $0.1 \mathrm{~N}-\mathrm{NaOH}$ solution. The absorption spectrum was observed using a Beckman $^{*}$ DB spectrophotometer in the region $700-300 \mathrm{~nm}$, but without demonstration of any characteristic peaks.

When ascorbic acid or thiouracil was incorporated in the medium, no pigment was produced (Table 1). These concen-

T a b l e 1. Some properties of the pigment of Aeromonas liquefaciens.

\begin{tabular}{ll}
\hline Parameter & Notes \\
\hline $\begin{array}{l}\text { colour } \\
\text { solubility in water at } \mathrm{pH} 7.0\end{array}$ & $\begin{array}{l}\text { brown-black } \\
\text { insoluble } \\
\text { solubility in } 0.1 \mathrm{~N}-\mathrm{NaOH} \\
\text { appearance in water }\end{array}$ \\
$\begin{array}{l}\text { soluble } \\
\text { evenly dispersed floc } \\
\text { formation of black precipitate with } \mathrm{FeCl}_{3}\end{array}$ & $\begin{array}{l}\text { precipitated (dissolves } \\
\text { with excess } \mathrm{FeCl}_{3} \text { ) }\end{array}$ \\
$\begin{array}{l}\text { precipitation from } \mathrm{NaOH} \text { solution by } \mathrm{HCL} \\
\text { reduction by } \mathrm{Na}_{2} \mathrm{~S}_{2} \mathrm{O}_{4}\end{array}$ & $\begin{array}{l}\text { precipitated } \\
\text { black } \rightarrow \text { tan } \\
\text { reoxidation by } \mathrm{K}_{4}\left[\mathrm{Fe}(\mathrm{CN})_{6}\right] \\
\text { absorption spectrum }(350-650 \mathrm{~nm})\end{array}$ \\
$\begin{array}{l}\text { tan } \rightarrow \text { black } \\
\text { production in the presence of } 0.33 \%\end{array}$ & no characteristic peaks \\
$\begin{array}{l}\text { ascorbic acid } \\
\text { production in the presence of } 0.33 \%\end{array}$ & inhibition \\
thiouracil & inhibition \\
\hline
\end{tabular}

trations of ascorbic acid or thiouracil did not have any influence on the bacterial growth, as examined by measurements of the turbidity.

\section{The biosynthesis of the pigment}

In order to approach the generally accepted pathway for melanin biosynthesis reproduced in Fig. 1 (Mason 1959) to the organism in question, the demonstration of phenoloxidase enzymes was of particular interest. The presence of these enzymes in aerobically incubated cultures of Ae. liquefaciens was demon-

* Beckman Instruments Inc., Fullerton, California, USA. 


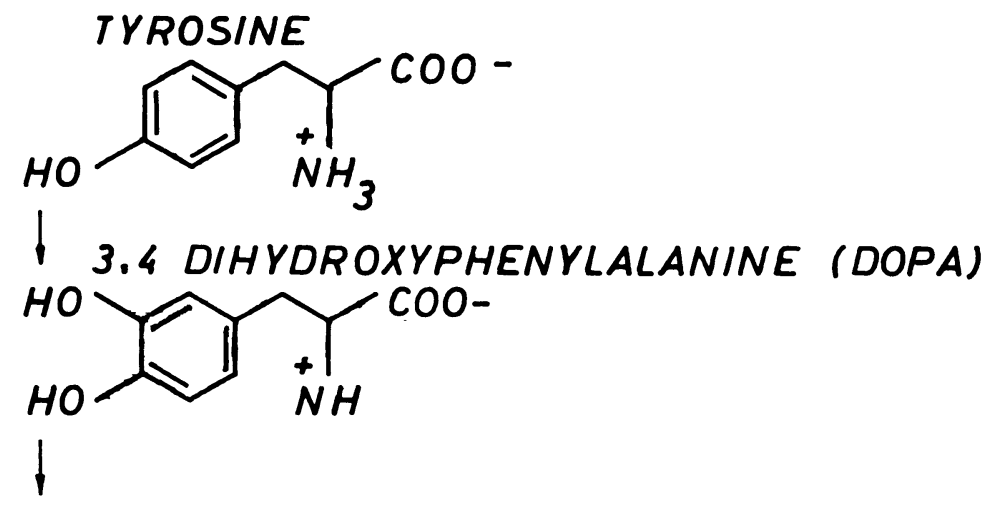

DOPA QUINONE

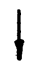

LEUCO DOPACHROME

1

DOPACHROME (RED)

1

5. 6-DIHYDROXYINDOLE

$\uparrow$

INDOLE 5.6- QUINONE

$\downarrow$

MELANOCHROME

$\downarrow$

\section{MELANINE}

Figure 1. Enzymatic oxydation of tyrosine to melanine.

strated by adding culture filtrates, harvested after incubation for 4 days, to solutions or agar-gels containing DL-dopa or catechol. Within $10 \mathrm{~min}$. the appearance of a pink colouration was observed and $1 \mathrm{hr}$. later the colour changed to dark brown, and finally to black. Corresponding experiments carried out with DL-tyrosine resulted in weaker reactions. The suspension of the washed and disintegrated cells did not oxidize DL-dopa, DLcatechol or DL-tyrosine. These reactions were controlled by using 
T a b le 2. Pigment prơduction from 3 melanin precursors catalyzed by enzymes produced by Aeromonas liquefaciens.

\begin{tabular}{lccc}
\hline Enzyme source & \multicolumn{3}{c}{ Precursor } \\
\cline { 2 - 4 } & DL-dopa & Catechol & DL-tyrosine \\
\hline culture filtrate & + & ++ & + \\
disintegrated cells & - & - & - \\
0.1 M phosphate buffer & - & - & - \\
pH 6.8 (Control) & - & - & - \\
\hline
\end{tabular}

+ and ++ : Various degrees of pigment formation.

-: No pigment formation.

saline extracts of potatoes, as potatoes are known to contain phenoloxidases (Lerner \& Fitzpatrick 1950).

During the period of pigment production the $\mathrm{pH}$ in the peptone water cultures changed from 6.3 to 8.0. However, if the $\mathrm{pH}$ of the peptone water, prior to incubation, was adjusted to $\mathrm{pH}$ values near 6.0 using phosphate buffers, the pigment production was inhibited, as shown in Table 3 . The bacterial growth in these media with adjusted $\mathrm{pH}$ was almost normal, as shown by the examination of the turbidity after incubation. In order to determine the effect of DL-tyrosine, DL-asparagine, DL-serine, DLisoleucine, DL-methionine, DL-valine, DL-tryptophan, DL-phenylalanine on the pigment production, the amino acids were added to the defined basal medium to a concentration of $0.1 \%$. Addition of the listed amino acids did not result in any visible change in bacterial growth or in the $\mathrm{pH}$ value of the basal medium.

However, none of the tested amino acids was able to induce

T a ble 3. The effect of the pH of the medium on the production of the pigment of Aeromonas liquefaciens.

\begin{tabular}{llllll}
\hline & \multicolumn{3}{c}{$\mathrm{pH}$ value of the tested media } \\
\cline { 2 - 5 } & 6.5 & 7.0 & 7.5 & 8.0 \\
\hline $\begin{array}{l}\text { basal medium } \\
\text { basal medium with } 0.1 \% \text { DL-tyrosine } \\
\text { peptone water }\end{array}$ & - & - & - & + & + \\
\hline
\end{tabular}

$(+),+$ and ++ : Various degrees of pigment production.

-: No pigment production. 
pigment production in these media at $\mathrm{pH}$ 6.5. The $\mathrm{pH}$ values of the media were adjusted to 7.0, 7.5 and 8.0, and the same amino acids were added to the tubes before inoculation and incubation at $30^{\circ} \mathrm{C}$. Only DL-tyrosine seemed to induce the pigment production (Table 3 ).

\section{DISCUSSION}

The results indicate that Ae. liquefaciens requires similar atmospherical and nutritional conditions for pigment production as does Ae. salmonicida (Bacterium salmonicida) (Griffin et al. 1953). The lag in appearance of the pigment during the first period of incubation may be analogous to the "induction period" for melanin biosynthesis in the presence of oxygen, as described by other authors (Griffin et al.).

The properties of the Ae. liquefaciens pigment, which are summarized in Table 1, seem to be similar to the properties of the synthetic dopa-melanin described by Mencher \& Heim (1962). However, it should be emphasized that the solubility in water differs from that of the Ae. salmonicida pigment (Griffin et al.).

Inhibition of the biosynthesis was clearly demonstrated on addition of ascorbic acid and thiouracil to the culture medium. Ascorbic acid is known to be an inhibitor of melanogenesis because of its reducing capacity, while thiouracil combines with copper ions which are necessary for phenoloxidase activity (Lerner \& Fitzpatrick 1950).

The demonstration of enzyme activity which converts the DL-tyrosine or DL-dopa into melanine (Fig. 1) was of particular interest for the biosynthesis of the pigment. Melanins are known to be formed by the enzymatic oxydation of phenols (Mason 1959). Systems which form melanins occur throughout the phylogenetic scale, and many phenolic substances act as precursors for the biosynthesis (Fox 1953, Mason 1955). Melanins are still identified by ambiguous tests which are based upon their phenolic or quinonoid properties, and upon the simultaneous presence of phenol oxidases (Mason 1948). The enzymes are, however, not specific (Yasunobu 1959) and the structures of the pigments are uncertain. For these reasons it is important to characterize, by experiment, each substance which is designated a melanin. Both DL-tyrosine, DL-dopa and catechol may act as precursors for melanin formation (Mason 1959). As shown in Table 2 the enzymes of Ae. liquefaciens are able to use these phenols as pre- 
cursors for melanin biosynthesis. It may therefore be concluded that the enzymes are phenol oxidases. The enzymes were demonstrated in culture filtrates, but not in suspensions of disintegrated cells (Table 2). This may possibly explain the observations that the colonies on skim milk agar developed colour only after prolonged incubation, in contrast to the rapid pigmentation of the medium.

The inhibition of pigment production by lowering the $\mathrm{pH}$ of the medium was effectively demonstrated (Table 3 ), as was the induction of pigment production by increasing the $\mathrm{pH}$ of the basal medium containing DL-tyrosine. This specific pH-dependence of the biosynthesis may be seen in connection with the alkaline conditions for optimal activity for other enzymes produced by Ae. liquefaciens (Dahle 1971).

The melanin pigment of Ae. liquefaciens seems to be related to the other microbial melanins referred to. However, the significance of the pigment as a criterium for the identification of strains which are pathogenic to certain animals or fishes is not yet known.

\section{REFERENCES}

Blackberg, S. N. \& J. O. Wanger: Melanuria. J. Amer. med. Ass. 1933, $100,334-336$.

Carberry, J. T.: Ulcerative dermal necrosis of salmonicids in Ireland. Symp. zool. Soc., London 1968, No. 24, 39-.49.

Cooper, J. A. \& F. Christine Brown: A rapid semi-quantitative method for the assay of tyrosinase activity. Clin. chim. Acta 1956, 1, $301-304$.

Dahle, H. K.: Enzymoserological separation of bacterial proteinases. Acta path. microbiol. scand. 1969, 76, 143-148.

Dahle, $H$. K.: Regulation of the proteinase production in two strains of Aeromonas. Acta path. microbiol. scand. 1971, 79, 739-746.

Fox, D. L.: Animal Biochromes and Structural Colours; Physical, Chemical, Distributional and Physiological Features of Coloured Bodies in the Animal World. Cambridge Univ. Press, London and New York 1953.

Griffin, Philip J., S. F. Snieszko \& S. B. Friddle: Pigment formation by Bacterium salmonicida. J. Bact. 1953, 65, 652-659.

Holt, G. \& T. Håstein: Furunculosis in fish in Norway. Nord. Vet.Med. 1970, 22, 505-509.

Lerner, A. B. \& T. B. Fitzpatrick: Biochemistry of melanin formation. Physiol. Rev. 1950, 30, 91-126.

Mason, H. S.: Classification of melanins. N.Y. Acad. Sci. Spec. Publ. 1948, 4, 399-405.

Mason, H. S.: Comparative biochemistry of the phenolase complex. Advanc. Enzymol. 1955, 16, 105-184. 
Mason, H. S.: Structure of melaniıs. In Gordon, M., ed.: Pigment Cell Biology. Acad. Press, New York 1959, 563-582.

Mencher, J. R. \& A. H. Heim: Melanin biosynthesis by Streptomyces lavendulae. J. gen. Microbiol. 1962, 28, 665-670.

Meyer, F. P.: Field treatments of Aeromonas liquefaciens in golden strimers. Progve Fish Cult. 1964, 26, 33-35.

Rock, L. F. \& H. M. Nelson: Charmel catfish and gizzard shad mortality by Aeromonas liquefaciens. Progve Fish Cult. 1965, 27, $138-141$.

Ross, A. J.: Isolation of a pigment producing strain of Aeromonas liquefaciens from silver salmon (Oncorhynchus kisutch). J. Bact. 1962, 84, 590-591.

Yasunobu, K. T.: Mode of action of tyrosinase. In Gordon, M., ed.: Pigment Cell Biology. Acad. Press, New York 1959, 583-608.

\section{SAMMENDRAG}

Produksjon og noen egenskaper hos det brune pigment fra Aeromonas liquefaciens.

De optimale atmosfære- og temperaturforhold for pigmentproduksjon hos Ae. liquefaciens ble funnet ả være aerob inkubasjon ved $30^{\circ} \mathrm{C}$, og pigmentets egenskaper tilsvarer egenskapene til det syntetiske dopamelanin som det refereres til. Enzymet phenoloxidase ble påvist i kulturfiltrat av Ae. liquefaciens, men ikke i ekstrakt av knuste bakterieceller. Som byggesteiner for pigment-produksjonen ble DLtyrosin, DL-dopa og catechol brukt med suksess, mens flere andre aminosyrer ikke induserte pigmentproduksjonen. Betydningen av pigmentet som kriterium for identifikasjon av stammer som er patogene for enkelte dyr eller fisk er ikke kjent.

(Received June 7, 1971).

Reprints may be requested from: Kjell Aurstad, The Department of Food Hygiene, Veterinary College of Norway, Postbox 8146, Oslo Dep., Oslo 1, Norway. 